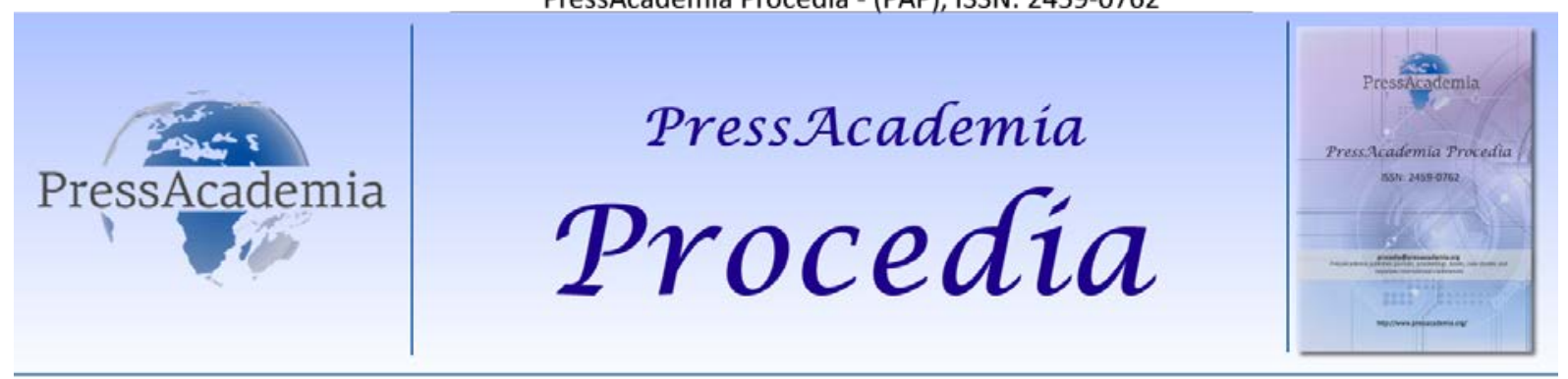

Global Business Research Congress (GBRC), June 4-5, 2015, Istanbul, Turkey.

\title{
COMPETENCY BASED HUMAN RESOURCE MANAGEMENT: A STUDY ON FOOD INDUSTRY FIRM
}

\section{DOI: 10.17261/Pressacademia.2016118144}

\author{
Ali Sahin Ornek ${ }^{1}$, Tanju Colakoglu ${ }^{2}$, Adem Sacan ${ }^{3}$ \\ ${ }^{1}$ Canakkale Onsekiz Mart University, asornek@hotmail.com \\ ${ }^{2}$ Canakkale Onsekiz Mart University, tanjucolakoglu@gmail.com \\ ${ }^{3}$ Canakkale Onsekiz Mart University, ademsacan13@gmail.com
}

\begin{abstract}
The purpose of the study is an evaluation of food industry workers' perceptions about varied competency dimensions. The study consists of workers that are employed in a firm operating at food industry in Turkey. As a quantitative research, this study uses survey method to collect data directly from target group. Sample is formed by voluntary participation. Survey is consisted of demographic questions and competency related questions. In order to clarify questionnaire' items the competency related questions section (which was originally 24 item survey) is transformed into a 31 item survey. The sample is narrowed as "the employees who are hired according to competency based recruiting applications" by first question of survey. With this regulation the expectation about this study is to maintain perceptions of workers who are recruited by competency based applications. The involved ideas of workers who are directly affected by competency based management are intended to be the mainly expected finding. After organization process of questionnaires forms, 225 of them selected as qualified. Data is entered to SPSS program from these qualified sources. The measured reliability of data is , 89 according to Cronbach's Alpha Reliability analysis. In addition to exposure interactions among competency dimensions; variations between these dimensions depending on demographic variables are found out.
\end{abstract}

Keywords: Competency, competency perceptions, competency analysis, competency based recruiting, competency based management. JEL Codes: J24, M12, M53, 015.

\section{INTRODUCTION}

Competency is vital for competing companies in today's world and that makes competencies important for employers. This importance is one of the reasons that the concept of competency based management is developed. Competencies are important in many areas such as forming job descriptions, determining the recruiting qualifications, planning the occupational retraining programs, etc.

It's clear that competencies are important for managers targeting success above others. But is this opinion shared by employees as well? What are the ideas of employees about these competencies? Which competencies are important for employees and which are less important? This study aims to find out the answers of these questions.

To find answers to questions mentioned above we used survey method in our research. Survey questions the perceptions of differentiated levels of staff (including employee to director) about competency based actions. 
These competency based actions were competency-based selection and placement, competency-based career planning, competency-based performance management, competency-based education and development and competency-based compensation management.

\section{LITERATURE REVIEW}

Competency- Competency is defined as the ability and capability of an individual to perform better in a given situation (Sita and Pinepati 2013). Competencies are characteristics of individuals used in appropriate, consistent ways in order to achieve desired performance. These characteristics are consist of knowledge, skills, aspects of self-image, social motives, traits, thought patterns, mind-sets, and ways of thinking, feeling, and acting (Dubois et al 2004: 16). Competency may also be defined as groups of knowledge, skills and specialties that are (Elataş 2010: 16);

- effects most of work related role and responsibilities of individuals;

- related with work performance;

- measurable at accepted standards;

- can be advanced with education and development.

Competence concept is first used in organization and management literature by Selznick as 'distinctive competencies' in 1957. The term is used to explain the process of key factors for success but it didn't popularly accepted on that time. The word competence is first used as a human related subject by White in 1959 . Finally the concept became popular with McClelland's paper 'Testing for Competence Rather Than Intelligence' in 1973. With Behavioral Competence Approach McClelland suggests evaluation based on criteria (Çınar 2010: 1).

McClelland proposed the term "professional competency" to criticize existing approach that assessing individual ability based on only intelligence tests results. Professional competencies include dimensions such as individual characteristics and behaviors, including skills, knowledge and attitudes; these components interact simultaneously and are difficult to differentiate (Jeou-Shyan et al 2011: 1045).

McClelland was intending to reveal work efficiency by relating work efficiency with worker's personal characteristics. Competency based management approach supported with fallowing studies. Richard Boyatzis, who defined competency as "an underlying characteristic of an individual which is causally-related to effective or superior performance" is one of these supporters with scientific contributions (Rejas-Muslera et al 2012: 118).

Competency-based management focuses on employee as talent management. This requires analysis of the competencies (the knowledge, skills and personal attributes) of employees that are required for organizations success about their goals (Bonder et al 2011: 2). Competence management covers fallowing activities (Lindgren et al 2004):

- definition of the organization's competence needs,

- calculation the competence gap between needed and actual competence,

- providing competence by recruiting,

- developing competence with training and coaching,

- selecting right employees to projects.

Competency types - During 1980ies Kenny defined 12 areas of core competencies for trainers as follows (Keny 1982: 145): Administration, Communication, Course design, Evaluation, Group dynamics process, Learning theory, Manpower planning, Person/organization/interface, Teaching practice, Training equipment and materials, Training needs analysis, Research and development.

Due to various studies on this field there are examples competency classifications. More recently Jeou-Shyan and colleagues categorized managerial competencies with 17 primary items and 66 sub-competencies items. These primary managerial competencies were; Personal relationship, Communication, Leadership, Implementation, Strategic management, Analysis, Problem solving, Human resource management, Field management, Expert knowledge, Financial management, Marketing, Culture, Self-management, Attitude, 
Foreign language, Others (Jeou-Shyan et al 2011: 1047). These samples show that different competency types may be generated according to relative aimed purposes.

Today's organizations are operating at project-based sectors. At these sectors there is a significant link between the performances of project managers with the performance of the organization. To evaluate performance of knowledge competence, project manager performance competence can be demonstrated by assessing project-related actions and outcomes. That means project managers must apply their knowledge to meet project outcomes (Ahsan et al 2013:39).

Different organizations are in need of different set of competencies. This is the reason that organizations have to identify competency types. These identified competencies will be useful in recruitment and selection, performance management, training and development, career development and compensation (Mukhopadhyay et al 2011: 154). This identification is possible with competency analysis.

Competency Analysis - Competency analysis is useful in many situations. These areas are can be titled as fallows (Gayeski et al 2007: 10):

- Creating and updating job descriptions

- Recruiting and selecting employees

- Designing and evaluating training and career education

- Developing incentive and reward systems

- Creating succession plans

Similarly Horng and Wang defined valid profile of occupation as (Horng and Wang 2003: 27):

- basis for training course development,

- a tool for performance assessment,

- a basis for selecting job applicants.

Focused on costs developing a curriculum (DACUM) was one of the best choices for process of job analysis. In order to challenge with fast change and need of adaptation the future developments of industry, Occupational Competency Analysis Profile (OCAP) is formed. OCAP "contains units, competencies and competency builders that identify the occupational, academic and employability skills needed to enter a given occupation of items identify the knowledge, skill, and attitudes essential for entry-level employment" (Horng and Wang 2003: 2627).

\section{PURPOSE OF RESEARCH AND RESEARCH METHODOLOGY}

\subsection{PURPOSE OF THE SEARCH}

The purpose of the study is an evaluation of food industry workers' perceptions about competency dimensions. The application group of study is accepted as a group of workers employed in a firm operating at food industry in Mersin, Turkey.

\subsection{RESEARCH METHODOLOGY}

Survey method was used for the competency analysis. The main frame of survey questions are taken from Elataş (2010). The original reliability value of survey was ,823. Questionnaire is consists of two sections. First section includes 7 statements. These statements are demographic questions (age, sex, education etc.) for applicants. Second section was including 24 questions developed to measure perceptions of benefit based on competence. Number of questions of Questionnaire increased to 31 in order to clarify the existing questions. These statements are grouped in five dimensions according to application fields. These fields are given as follows:

- Competency-based selection and placement (5 questions)

- Competency-based career planning (5 questions)

- Competency-based performance management (10 questions)

- Competency-based education and development (5 questions) 
- Competency-based compensation management (6 questions)

\subsubsection{The Universe and Sample of Study}

The universe of study is consists of workers that are employed in food industry in Turkey. Workers employed in a firm operating at food industry in Mersin Turkey are selected as sample. The total employee number of firm is 260. 250 of employees participated to survey.

\subsubsection{Questionnaire Questions}

The survey is applied with face to face survey technic. In order to reach most of the universe of total 260 employees 250 of employees of firm selected by random sample method. After a preliminary valuation of answered 250 surveys 225 survey forms are selected to be qualified. These 225 survey forms are used as data set.

Total number of questions in questionnaire is 38.7 of questions are demographic related. 31 questions are set 5 answers Likert scale. The coding of this scale is: $1=$ Definitely Disagree, 2= Disagree, 3= Hesitant, 4= Agree, 5= Definitely Agree. The data is collected in 10 days of process. The data is analyzed with SPSS 19 student edition.

\section{RESEARCH FINDINGS}

Reliability of study; Cronbach's Alpha Reliability Analysis was applied to 31 statement and 7 demographic related statement excluded. The results are given as follows.

Table 1: Cronbach's Alpha Reliability Analysis

\begin{tabular}{|l|l|}
\hline \multicolumn{2}{|l|}{ Reliability Analysis } \\
\hline Cronbach's Alpha & Items \\
\hline, 888 & 31 \\
\hline
\end{tabular}

Reliability Analysis results with an cronbach's alpha value ,888 which is even higher than the original survey which was also high above \%70 acceptability level. According to this result, the 31 statement successfully measures the target event. Kaiser-Meyer-Olkin (KMO) test results are given as fallows. According to this results Bartlett's and Kaiser-Meyer-Olkin values are significant.

\begin{tabular}{|l|r|r|}
\hline Table 2: KMO and Bartlett's Test \\
\hline Kaiser-Meyer-Olkin Measure of Sampling Adequacy. &, 909 \\
\hline Bartlett'sTestof Sphericity & Approx. Chi-Square & 3217,543 \\
\cline { 2 - 3 } & df & 496 \\
\cline { 2 - 3 } & Sig. &, 000 \\
\hline
\end{tabular}

Table 2 is showing the information about participants of survey. According to table, 34 of personnel are female and 191 are male of total 225 participants. Moreover 64 of participants are single and 158 of them are married. Age of the personnel participated in survey spread by \%57,3 ratio and 129 in number at age between 26-35, \% 20,7 ratio and 47 in number at age between $36-45$. This means most of participants (\%78) are at an age range called as medium age group.

Education levels of participants differ from secondary school to graduate levels. The biggest group is $\% 48,9$ and 110 of the participants that are high school graduated while $\% 20,4$ and 46 of them are having an associate degree. The years of working is defined as Seniority in this survey. According to scale \%62,2 and 140 of the participants have a seniority of 5 years or under while $\% 29,8$ and 67 of them stated that they have a seniority of 6-10 years.

Study also aimed to maintain knowledge about monthly wages of participants. Monthly wages of participants is questioned by different fee levels ranged between 1000 to 4000 Turkish liras. The results show that most of the participants with \% 51,1 have monthly income between 1001-2000 Turkish liras. Also \% 28,9 of participants have monthly income of 1000 Turkish liras or under. 
Table 3: Demographics

\begin{tabular}{|c|c|c|c|c|c|}
\hline Gender & $\mathbf{N}$ & $\%$ & Fee Range (Turkish lira) & $\mathbf{N}$ & $\%$ \\
\hline Female & 34 & 15,1 & Less than 1000 & 65 & 28,9 \\
\hline Male & 191 & 84,9 & $1001-2000$ & 115 & 51,1 \\
\hline \multicolumn{3}{|l|}{ Age } & $2001-3000$ & 40 & 17,8 \\
\hline Under 25 & 44 & 19,6 & 3001 and over & 5 & 2,2 \\
\hline $26-35$ & 129 & 57,3 & \multicolumn{3}{|l|}{ Status } \\
\hline $36-45$ & 47 & 20,9 & Employee & 60 & 26,7 \\
\hline $46-55$ & 4 & 1,8 & Expert & 43 & 19,1 \\
\hline $56-65$ & 1 & 4 & Expert Assistant & 28 & 12,4 \\
\hline \multicolumn{3}{|l|}{ Marital status } & Food Technician & 15 & 6,7 \\
\hline Single & 64 & 28,4 & Machine Operator & 30 & 13,3 \\
\hline Married & 158 & 70,2 & Section Chief & 26 & 11,6 \\
\hline Other & 3 & 1,3 & Director & 5 & 2,2 \\
\hline \multicolumn{3}{|l|}{ Education } & Vice Director & 4 & 1,8 \\
\hline Secondary School & 29 & 12,9 & Others & 14 & 6,2 \\
\hline High School & 110 & 48,9 & \multicolumn{3}{|l|}{ Seniority } \\
\hline Associate Degree & 46 & 20,4 & Under 5 years & 140 & 62,2 \\
\hline License & 36 & 16,0 & $6-10$ & 67 & 29,8 \\
\hline \multirow[t]{3}{*}{ Graduate } & 4 & 1,8 & $11-15$ & 15 & 6,7 \\
\hline & & & $16-20$ & 2 & 9 \\
\hline & & & $21-25$ & 1 & 4 \\
\hline Total & 225 & 100,0 & Total & 225 & 100,0 \\
\hline
\end{tabular}

Finally demographic information part of survey ends with statements about status. Status distribution shows 60 of participants are employees, 43 of them are expert, 28 of them are Expert Assistant, 15 of them are Food Technician, 30 of them are Machine Operator, 26 of them are Section Chief, 5 of them are Director, 4 of them are Vice Director and 14 of them are working on various areas.

\section{Data analysis of answers to statements grouped according to dimensions of competency based actions}

Competency Based Recruitment and Placement Statements: The most accepted statement in this set is "I'm recruited to a job proper to my competencies through competency based recruitment". This means its most important determining think for employees is to be recruited in a job fitting to their personal competencies.

Table 4: Competency Based Recruitment and Placement Perceptions

\begin{tabular}{|l|l|l|}
\hline Statements & Mean & Deviation \\
\hline I'm recruited to a job proper to my competencies through competency based recruitment & 3,83 &, 684 \\
\hline $\begin{array}{l}\text { I applied to right job because competency based job advertising indicates the required } \\
\text { competencies properly. }\end{array}$ & $3,79,656$ \\
\hline $\begin{array}{l}\text { I think I have the right competencies required for the job questioned in proficiency testing } \\
\text { forms. }\end{array}$ & 3,80 &, 740 \\
\hline $\begin{array}{l}\text { I think the desired qualifications for the job in proficiency testing detected correctly. } \\
\text { I think my company hire the right employees with competency based recruitment and } \\
\text { placement. }\end{array}$ & 3,53 &, 755 \\
\hline
\end{tabular}

Competency Based Career Planning Statements: The most important statement for the firma employees among answers to Competency Based Career Planning related statements is "I think with directions of Competency Based Career Planning, I will be in right position fitting to my competencies in future". This gives a hint about building employee trust by using Competency Based Career Planning. 
Table 5: Competency Based Career Planning Perceptions

\begin{tabular}{|c|c|c|c|}
\hline Statements & Mean & Deviation & $\begin{array}{l}\text { Cronbach } \\
\text { Alpha }\end{array}$ \\
\hline $\begin{array}{l}\text { I think with directions of Competency Based Career Planning, I will be in right position fitting } \\
\text { to my competencies in future. }\end{array}$ & 3,81 & ,694 & \multirow{5}{*}{,883 } \\
\hline $\begin{array}{l}\text { Competency Based Career Planning and replacement planning system increases my } \\
\text { commitment to organization. }\end{array}$ & 3,73 & ,748 & \\
\hline $\begin{array}{l}\text { Competency Based Career Planning and replacement planning system increases my trust to } \\
\text { organization. }\end{array}$ & 3,72 & ,794 & \\
\hline $\begin{array}{l}\text { I consider "making a replacement plan about my competencies for an important position" is } \\
\text { a right application. }\end{array}$ & 3,71 & ,806 & \\
\hline Personnel turnover rate is decreased with Competency Based Career Planning & 3,62 & ,836 & \\
\hline
\end{tabular}

Competency Based Performance Management Statements: The perception of food company employees' as most important statement in Competency Based Performance Management related statements is "I think Competency Based Performance Management makes it possible to identify clearly how much I achieved my goals". Such performance evaluation maintains employees a vision of self-assessment.

Table 6: Competency Based Performance Management Perceptions

\begin{tabular}{|c|c|c|c|}
\hline Statements & Mean & Deviation & $\begin{array}{l}\text { Cronbach } \\
\text { Alpha }\end{array}$ \\
\hline $\begin{array}{l}\text { I think Competency Based Performance Management makes it possible to identify clearly } \\
\text { how much I achieved my goals. }\end{array}$ & 3,88 & ,734 & \multirow{10}{*}{,857 } \\
\hline $\begin{array}{l}\text { I think right career plan applications executed with Competency Based Performance } \\
\text { Management. }\end{array}$ & 3,80 & 674 & \\
\hline $\begin{array}{l}\text { I think right recruiting applications executed with Competency Based Performance } \\
\text { Management. }\end{array}$ & 3,77 & 770 & \\
\hline $\begin{array}{l}\text { I clearly understand my organization's expectations from me with performance measuring } \\
\text { systems that identify my competency levels. }\end{array}$ & 3,76 & 797 & \\
\hline $\begin{array}{l}\text { The personnel with insufficient level of competencies may be dismissed with competency } \\
\text { based performance evaluation. }\end{array}$ & 3,75 & 750 & \\
\hline $\begin{array}{l}\text { I think measuring adequacy of my competencies is a better method of performance } \\
\text { evaluation then measuring work results. }\end{array}$ & 3,75 & 807 & \\
\hline I think work performance is truly evaluated by measurable competency levels. & 3,73 & ,668 & \\
\hline $\begin{array}{l}\text { I think right education and development applications executed with Competency Based } \\
\text { Performance Evaluation. }\end{array}$ & 3,72 & ,722 & \\
\hline I think right waging applications executed with Competency Based Performance Evaluation. & 3,72 & 805, & \\
\hline $\begin{array}{l}\text { I think identification of personnel with insufficient level of competencies ensured with } \\
\text { Competency Based Performance Evaluation. }\end{array}$ & 3,70 & 775, & \\
\hline
\end{tabular}

Competency Based Education and Development Statements: The most approved statement in Competency Based Education and Development related statements become: "I think, through development of my weaknesses I became more beneficial employee for my company". This attitude relies on education since education has an effect of gaining experience. The employees will be more useful for company due to specific education about their work. 
Table 7: Competency Based Education and Development Perceptions

\begin{tabular}{|l|l|l|}
\hline Statements & Mean & Deviation \\
\hline $\begin{array}{l}\text { I think, through development of my weaknesses I became more beneficial employee for my } \\
\text { company. }\end{array}$ & 3,86 &, 738 \\
\hline $\begin{array}{l}\text { I can make my duty easier with Competency Based Education and Development activities } \\
\text { that results a growing in my self-confidence. }\end{array}$ & 3,84 &, 754 \\
\hline $\begin{array}{l}\text { My organization develops my insufficient competencies and that strengths my belief about } \\
\text { my importance for organization. }\end{array}$ & 3,82 &, 671 \\
\hline $\begin{array}{l}\text { I think my organization reaches it' purposes easily with education and development activities. } \\
\text { I reach my goals easily by adjustment of my insufficient competencies with education and } \\
\text { development methods. }\end{array}$ & 3,79 &, 775 \\
\hline
\end{tabular}

Competency Based Compensation Management Statements: The statement "I think my efficiency increases because the rewards determined according to competency levels and the ones deserve more earn more" is most approved statement in this 6 statements. Calculation of payments depending on competencies seems to be acceptable (fair) model for employees.

Table 8: Competency Based Compensation Management Perceptions

\begin{tabular}{|l|l|l|}
\hline Statements & Mean & Deviation \\
\hline $\begin{array}{l}\text { I think my efficiency increases because the rewards determined according to competency } \\
\text { levels and the ones deserve more earn more. }\end{array}$ & 3,89 &, 717 \\
\hline Setting wages according to competencies prevents waging inequality between employees. & 3,81 &, 794 \\
\hline Setting wage raises according to competencies work motivation. & 3,78 &, 761 \\
\hline Setting wages according to competencies prevents unfair earnings among employees. & 3,76 &, 741 \\
\hline Setting my wage according to my competencies makes me think I get what I deserved. & 3,76 &, 792 \\
\hline $\begin{array}{l}\text { I think Competency Based Compensation is a fair waging system since it depends on my own } \\
\text { competency level. }\end{array}$ & 3,73 &, 811 \\
\hline
\end{tabular}

\section{CONCLUSION AND ESTIMATIONS}

The survey study shows the perceptions of employees in a food industry firm. The results point out the most important competency based factors for employees. Depending on these perceptions, employers may develop a desirable atmosphere for employees.

As mentioned above having a job fitting to personal competencies is important for employees. This means the organizations that pay attention to this sensitivity will ensure effectiveness of employees. Also employees will perform willingly in such environment. Another important effect of competency perceptions is that employees trust Competency Based Career Planning about their future. Since employees have such trust, Career Planning becomes more important for the motivating employees with future career expectations.

Competency Based Performance Management allows employees to evaluate their success correctly. From this point of view, the firms that pay attention to performance evaluation of employees will constitute positive perception of their employees. Competency Based Education gives employees exactly needed knowledge about their work. And since this education directly effects their performance development it also gives individual satisfaction addition to increased utilities for the firm. Another competency based implementation is given as Competency Based Compensation Management (CBCM). The execution of CBCM creates a perception 
of fairly distributed and deserved income. This perception will motivate employees and also increases productivity as well.

Study shows that competency perceptions of employees have many effects on employees and employee related results (like effectiveness, morale etc.) as well. Since this is a pre-study about these relations more detailed results will be achieved with our following researches.

\section{REFERENCES}

Ahsan Kamrul, Ho Marcus, Khan Sabik (2013) Recruiting Project Managers: A Comparative Analysis of Competencies and Recruitment Signals From Job Advertisements. Project Management Journal, Vol. 44, No. 5, 36-54.

Akgeyik Tekin (2002), İnsan Kaynaklarında Yetkinlik Yönetimi, iktisat Fakültesi Mecmuası, Vol: 52, No: 1.

Bonder Arieh, Bouchard Carl-Denis, Bellemare Guy (2011). Competency-Based Management - An Integrated Approach to Human Resource Management in the Canadian Public Sector. Public Personnel Management Volume 40 No. 1 Spring 2011.

Çınar Zehra (2010), Yetkinlik Bazlı Performans Değerlendirme, http://www.makaleler.com/yetkinlik-bazl\%C4\%B1-performansde\%C4\%9Ferlendirme Access date: 14.05.2015.

Dubois David D., Rothwell William J., Stern Deborah Jo King, Kemp Linda K. (2004). Competency-Based Human Resource Management. ${ }^{\text {st }}$ edition. Davies-Black Publishing, Mountain View, California.

Elataş Ercan (2010), Yetkinlik Bazlı İnsan Kaynakları Yönetimi Uygulamaları ve Algılanan Faydalarına iliş̧kin Bir Araştırma, İstanbul UniversitySocial Science Institute, Management Department, Human Resource Management master's thesis.

Gayeski Diane M., Golden Thomas P., Andrade Stephen, Mason Hilary (2007). Bringing Competency Analysis Into The 21st Century. Performance Improvement, vol. 46, no. 7, August 2007.

Horng Jeou-Shyan, Wang Li-Lin (2003). Competency Analysis Profile of F\&B Managers of Internatıonal Tourist Hotel in Taiwan. Asia Pacific Journal of Tourism Research Volume 8 Issue 1.

Jeou-Shyan Horng, Hsu Hsuanc, Liu Chih-Hsingd, Lin Linb, Tsai Chang-Yene (2011).Competency analysis of top managers in the Taiwanese hotel industry. International Journal of Hospitality Management 30 (2011) 1044-1054.

Kenny John B. (1982), Competency Analysis for Trainers: A Model for Professionalization, Training and Development Journal, May 1982.

Mukhopadhyay Kankana, Sil Jaya, Banerjea N.R. (2011). A Competency Based Management System for Sustainable Development by Innovative Organizations: A Proposal of Method and Tool. Vision 15(2) 153-162. DOI: 10.1177/097226291101500206.

Rejas-Muslera Ricardo, Urquiza Alfonso, Cepeda Isabel (2012). Competency-Based Model Through It: An Action Research Project. Syst. Pract. Action Res. 25:117-135. DOI 10.1007/s11213-011-9213-9

Lindgren Rikard, Henfridsson Ola, Schultze Ulrike (2004). Design Principles for Competence Management Systems: A Synthesis of an Action Research Study. MIS Quarterly Vol. 28 No. 3, pp. 435-472/September 2004.

Sita Vanka, Pinapati Anitha (2013) Competency Management as a Tool of Talent Management: A Study in Indian IT. Organizations, Journal of Economic Development, Management, IT, Finance and Marketing, 5(1), March 2013, p: 44-56. 